\title{
Seabed Classification Using Multibeam Backscatter in G-Island, North Jakarta
}

\author{
Steven Solikin ${ }^{1}$, Henry M. Manik ${ }^{2 *}$, Sri Pujiyati ${ }^{2}$ and Susilohadi Susilohadi ${ }^{3}$ \\ ${ }^{1}$ Graduate School of Marine Technology, PMDSU Batch II, Bogor Agricultural \\ University, IPB Dramaga Campus, Bogor 16680, Indonesia \\ ${ }^{2}$ Department of Marine Science and Technology, Faculty of Fisheries and Marine \\ Science, Bogor Agricultural University, IPB Dramaga Campus, \\ Bogor 16680, Indonesia \\ ${ }^{3}$ Centre for Research and Development of Marine Geology, Ministry of Energy \\ and Mineral Resources, Jl. Dr. Djunjunan No. 236 Pasteur, Bandung, Indonesia \\ ${ }^{1}$ steven_solikin@apps.ipb.ac.id, ${ }^{2 *}$ henrymanik@ipb.ac.id, \\ ${ }^{2}$ sripujiyati@yahoo.com, ${ }^{3}$ s.susilohadi@mgi.esdm.go.id
}

\begin{abstract}
The use of data, including bathymetry and backscatter intensity, collected using multibeam echosounder (MBES) systems to characterize seabed types was evaluated in the G-Island sea, North Jakarta. A multibeam echosounder survey using Kongsberg EM 2040 with the frequency of $300 \mathrm{kHz}$ was done in October 31th - November $5^{\text {th }} 2016$. Ground-truth data in the form of grab samples were collected at 7 stations and were analyzed for grain size. Factor analysis of grain size and acoustic data identified two sedimentary types: coarse sand and very fine sand. A map of seabed classification was produced through a combination of information derived from backscatter data and morphological features derived from multibeam bathymetry, which were validated by ground-truth data.
\end{abstract}

Keywords: grain size, multibeam echosounder, North Jakarta, seabed classification

\section{Introduction}

Acoustical methods, especially swath techniques are very powerful as the main source of knowledge on bottom bathymetry and seafloor morphology [1]. It becomes the remotesensing tool that will provide the basis for identification, classifying, and mapping ocean resources [2]. Multibeam echo sounders (MBES) are now extensively used for these purposes, chiefly because they present technological capabilities, such as swath coverage, high-resolution bathymetry, and wide depth range [3].

Various methods of classifying MBES data into benthic habitat maps have been developed over the past two decades. Many algorithms have been developed to implement in the classifying methods. There are three types of MBES datasets commonly used as the sources for the classification process: backscatter mosaic, backscatter angular response and bathymetry. Backscatter was the main key to determine the seafloor condition. Backscatter intensity obtained from the receiver provide preliminary information on sediment types in sounding location spatially [4-8].

One of many approaches used to see the relationship between the acoustic waves angles and the backscatter received by the receiver on MBES is the Angular Range Analysis (ARA). This method is used to observe the response pattern of the seabed echo and the backscattering strength based on the emitted acoustic waves [9]. This study is

Received (July 19, 2018), Review Result (August 6, 2018), Accepted (August 20, 2018)

* Corresponding Author 
aimed to classify the seabed types in G-Island sea using backscatter intensity data from ARA and sediment grain size. Secondly, is to produce an accurate sediment distribution map in order to answer the challenge from Indonesia's government to make this country as the world maritime shaft.

The condition and distribution of sediment on the seafloor should be studied as a geological archive that must be owned by the State of Indonesia. The knowledge of seafloor types is able to provide various information and economic values for Indonesia itself. Research on the distribution of seafloor types is able to be used for coastal management and infrastructure planning. The use of multibeam echosounder as an instrument to perform wide mapping and high resolution is expected to be the right choice to get all information on the distribution of the seafloor types.

\section{Background - Multibeam Data and Seabed Mapping Theory and Applications}

Bathymetry data and backscatter data from multibeam echosounder provide complementary information for accurate seabed mapping. They used to describe seafloor morphology and seabed texture that are proxies of seabed physical properties.

\subsection{Backscatter}

Acoustic backscatter data, acquired by multibeam echosounder, records signal returns scattered back from the seabed. The recorded backscatter intensity from the seabed is a function of the absorption from the water medium, scattering of water-seabed interface, the incidence angle, and the seafloor topography [10]. After calibration and corrections, the backscatter intensity value is affected by three seabed physical properties: the acoustic impedance, seabed surface roughness, and volume heterogeneity [11-14]. Many studies indicate that acoustic backscatter strongly correlates with sediment mean grain size [1516]. Hard substrata, such as coral reef, could also be easily differentiated from soft sediment using backscatter data because of their very different hardness.

\subsection{Bathymetry}

Bathymetry data is not only needed for the correction of backscatter data, but also provides information on the morphology of the seafloor. The bathymetry data can derive many morphometric measures, such as slope and curvature [17-18]. The derived features can be a good indicators for substrate type. For example, hard substrates such as coral reefs are often located on high-relief seabed [19]. Bathymetry and seabed morphological features are also effective assessment for oceanographic processes that influence sediment transport, thus distribution of sediment.

\section{Materials and Methods}

In this section, we first describe the survey area and the acquisition of the multibeam data (Section 3.1). We then detail the methods used to process the raw multibeam data and use the angular response curves (Section 3.2). Figure 1 showed the flowchart of the overall data processing and analysis used in this study. Firstly, processed multibeam data were obtained from calibrating and cleaning the raw data. The processed multibeam data include bathymetry and backscatter data. From the bathymetry data, we derived a range of terrain variables. Next, the angular response curves were used to extract a number of features from multibeam data to obtain seabed classification and prediction maps. 


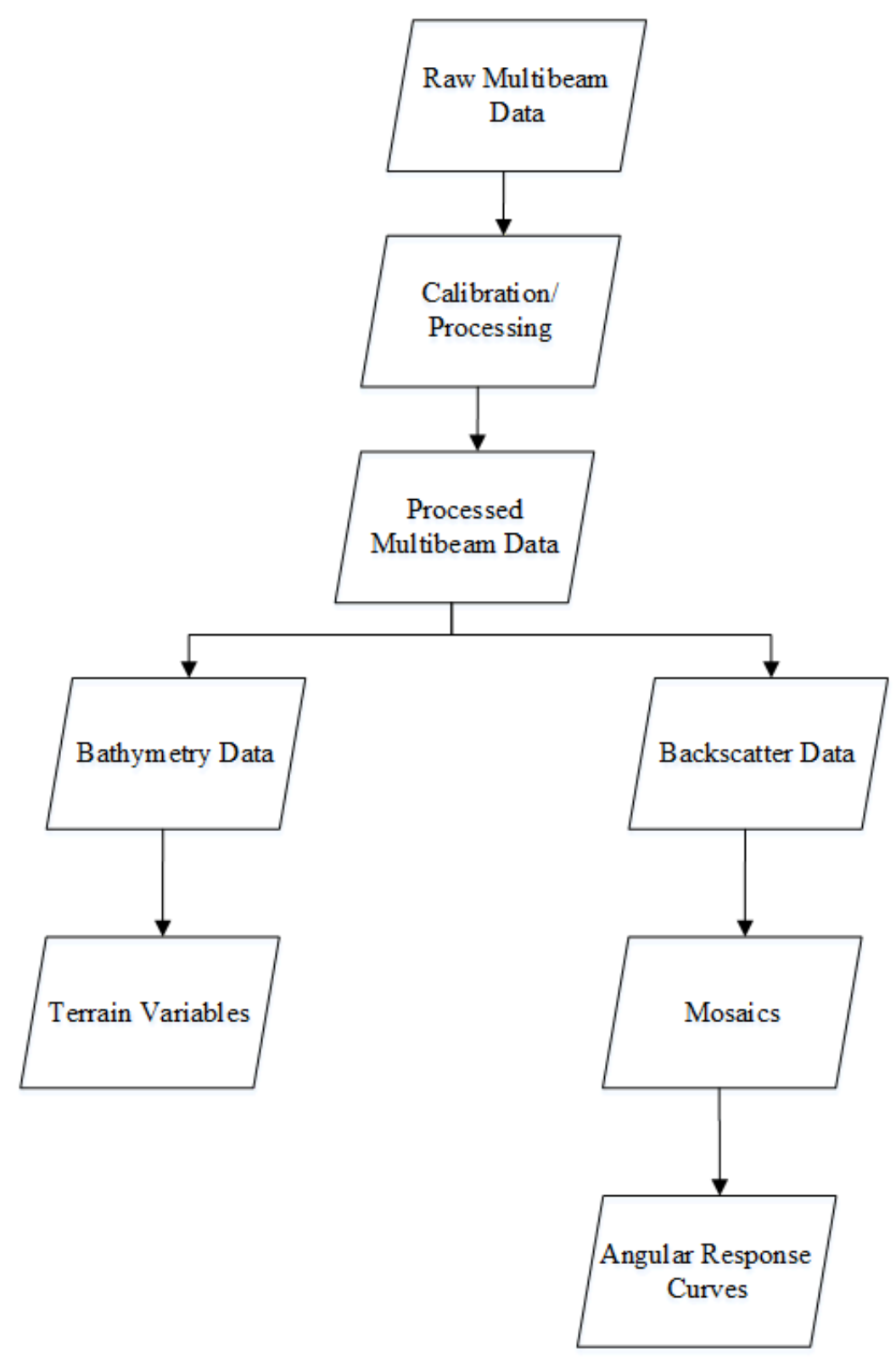

Figure 1. Summary of Workflow used for this Study

\subsection{Study Area and Survey}

The survey was conducted in October $31^{\text {th }}$ to November $5^{\text {th }}$ in G-Island sea, North Jakarta. Data taken in the survey consist of acoustic data and sediment samples. The acoustic data was acquired using multibeam echo sounder SIMRAD Kongsberg EM2040 with the frequency of $300 \mathrm{kHz}$, whereas the sediment samples were collected using sediment grab in 7 different locations inside the survey track. Figure 2 showed the survey location in G-Island sea.

The multibeam data were recorded using Kongsberg's Seabed Information System (SIS) software. Those were acquired in eleven tracks with the length of each track being an average of $5 \mathrm{~km}$ and the distance between each track is approximately $100 \mathrm{~m}$. The multibeam data consist of bathymetry and backscatter intensity data. The bathymetry data showed the depth of the water column, whereas the backscatter intensity data were used to classify the seabed type based on the backscatter energy value of each sediment type. 


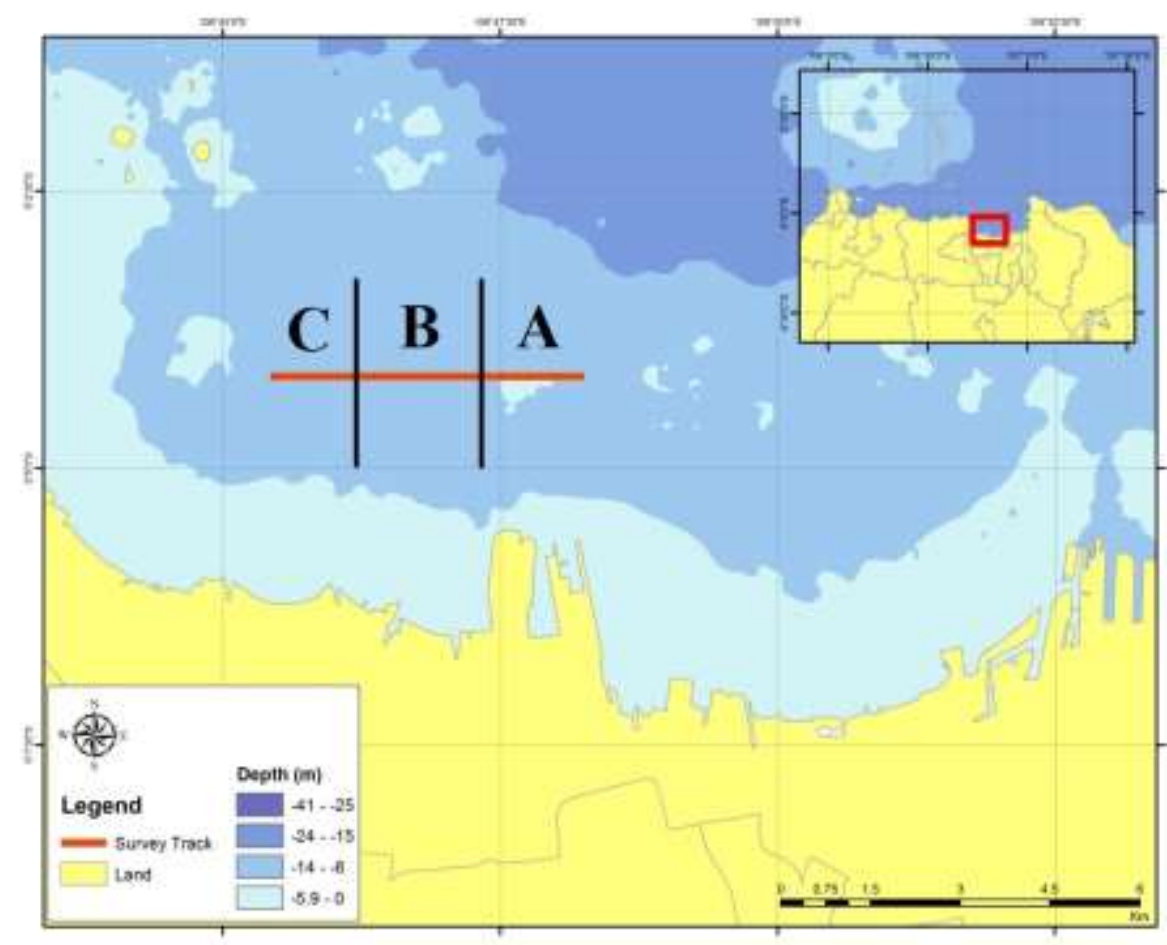

Figure 2. Survey Location Map in G-Island, North Jakarta. The Red Line Showed the Data Acquisition Track Using Multibeam Echosounder. The Survey Line is Divided into Three Areas in Order to be More Easily Displayed in the Results

\subsection{Processing of Raw Multibeam Data}

The backscatter intensity data was being processed by ARA method. ARA could give full information of backscatter value along sounding process of signal transmit. Backscatter analysis was performed based on backscatter surface in the covered area. The ARA equation to collect the backscatter value is given in the Eq. (1-4) [20]

$$
\begin{aligned}
& B=\frac{\text { Far-Near }}{\sin ^{2}\left(\theta_{f a r}\right)-\sin ^{2}\left(\theta_{\text {near }}\right)} \\
& A=\frac{\text { Far }+ \text { Near }}{2}-B\left(\frac{\sin ^{2}\left(\theta_{f a r}\right)+\sin ^{2}\left(\theta_{\text {near }}\right)}{2}\right) \\
& \text { Background Trend }=g \text { * } A+d \\
& \text { Fluid Factor }=\frac{-g A+B-d}{\sqrt{g^{2}+1}}
\end{aligned}
$$

where
A : Total gradient of the angular response;
B : Total intercept of the angular response;
Near : Average backscatter in the near range;
Far : Average backscatter in the far range;
$\mathrm{g} \quad$ : Slope of the background trend line;
d : Intercept of the background trend line;
$\theta_{\text {far }} \quad:$ Average incident angle of the sounding in the far range;
$\theta_{\text {near }} \quad$ : Average incident angle of the sounding in the near range.

The backscatter data had to be corrected by its beam pattern, named beam pattern correction. This correction compensate the backscatter intensity from all angle of the 
MBES backscatter data so the results will be more accurate. Figure 3 showed the sample of beam pattern correction.

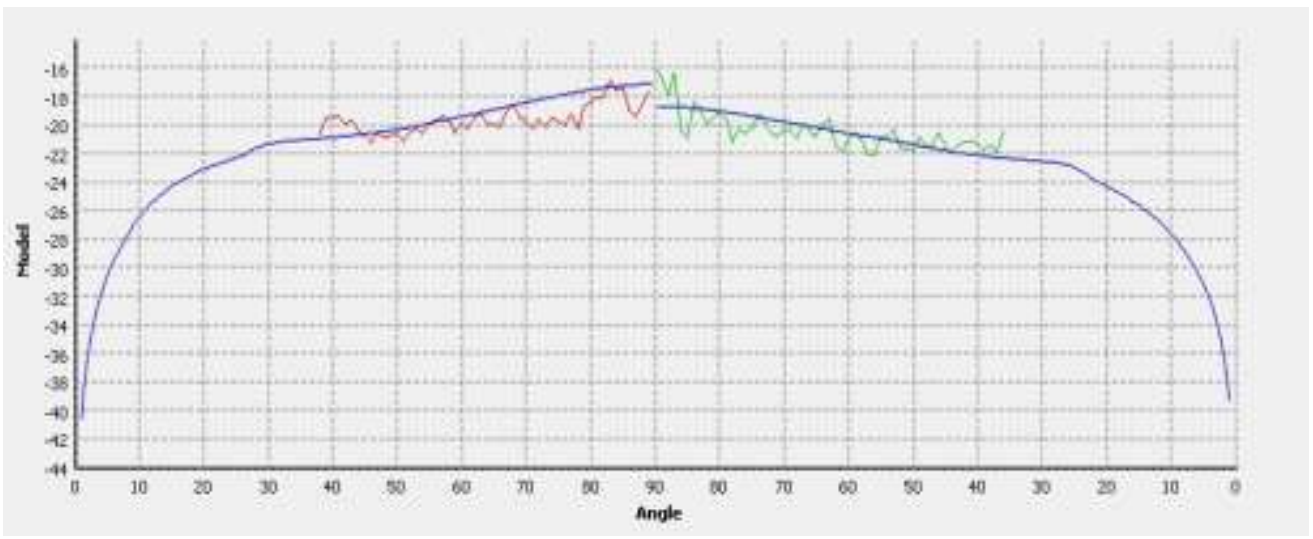

Figure 3. The Correction of the Beam Pattern. the Data Acquired in Starboard Side is Marked by Red Line, whereas Data Acquired in Port Side is Marked by Green Line, and the Model is Marked by Blue Line

\section{Results and Discussion}

The seven sediment samples are analyzed to get the mean grain size value. There are 6 samples categorized as coarse sand and there is one sample categorized as very fine sand. The backscatter intensity from the 7 sediment samples is ranged from -45.38 to $-34.71 \mathrm{~dB}$. The lowest value comes from PG3 that categorized as very fine sand. Table 1 showed the mean grain size and backscatter intensity from the seven sediment samples.

Table 1. Mean Grain Size and Backscatter Intensity from the Seven Sediment Samples

\begin{tabular}{|l|l|l|l|l|l|l|l|}
\hline $\begin{array}{l}\text { Diameter size } \\
(\mathrm{mm})\end{array}$ & PG1 & PG2 & PG3 & PG4 & PG5 & PG6 & PG7 \\
\hline $1-2$ & 0.302 & 0.199 & 0 & 0 & 0.362 & 0.257 & 0.082 \\
\hline $0.5-1$ & 2.916 & 3.124 & 2.097 & 1.549 & 3.221 & 2.919 & 2.047 \\
\hline $0.25-0.5$ & 5.414 & 5.272 & 4.748 & 4.81 & 4.575 & 4.733 & 4.87 \\
\hline $0.125-0.25$ & 3.561 & 3.608 & 3.65 & 3.92 & 3.437 & 3.703 & 3.605 \\
\hline $0.63-0.125$ & 3.123 & 3.153 & 3.573 & 3.523 & 3.183 & 3.407 & 3.443 \\
\hline $0-0.63$ & 2.767 & 3.428 & 4.924 & 4.579 & 4.538 & 4.44 & 4.656 \\
\hline Residue & 1.078 & 0.572 & 0.505 & 1.139 & 0.193 & 0.185 & 0.575 \\
\hline Total & 19.161 & 19.356 & 19.497 & 19.52 & 19.509 & 19.644 & 19.278 \\
\hline $\begin{array}{l}\text { Type } \\
\text { Coarse }\end{array}$ & $\begin{array}{l}\text { Coarse } \\
\text { sand }\end{array}$ & $\begin{array}{l}\text { Very } \\
\text { fine } \\
\text { sand }\end{array}$ & $\begin{array}{l}\text { Coarse } \\
\text { sand }\end{array}$ & $\begin{array}{l}\text { Coarse } \\
\text { sand }\end{array}$ & $\begin{array}{l}\text { Coarse } \\
\text { sand }\end{array}$ & $\begin{array}{l}\text { Coarse } \\
\text { sand }\end{array}$ \\
\hline $\begin{array}{l}\text { Backscattering } \\
\text { strength value } \\
\text { (dB) }\end{array}$ & -42.74 & -45.27 & -45.38 & -44.46 & -38.41 & -37.31 & -34.71 \\
\hline
\end{tabular}


The backscatter mosaic is the first step while creating the bathymetry and the classification. Backscatter mosaic is containing the backscatter intensity information in grey scale. The backscatter mosaic for this study is presented in Figure 4.
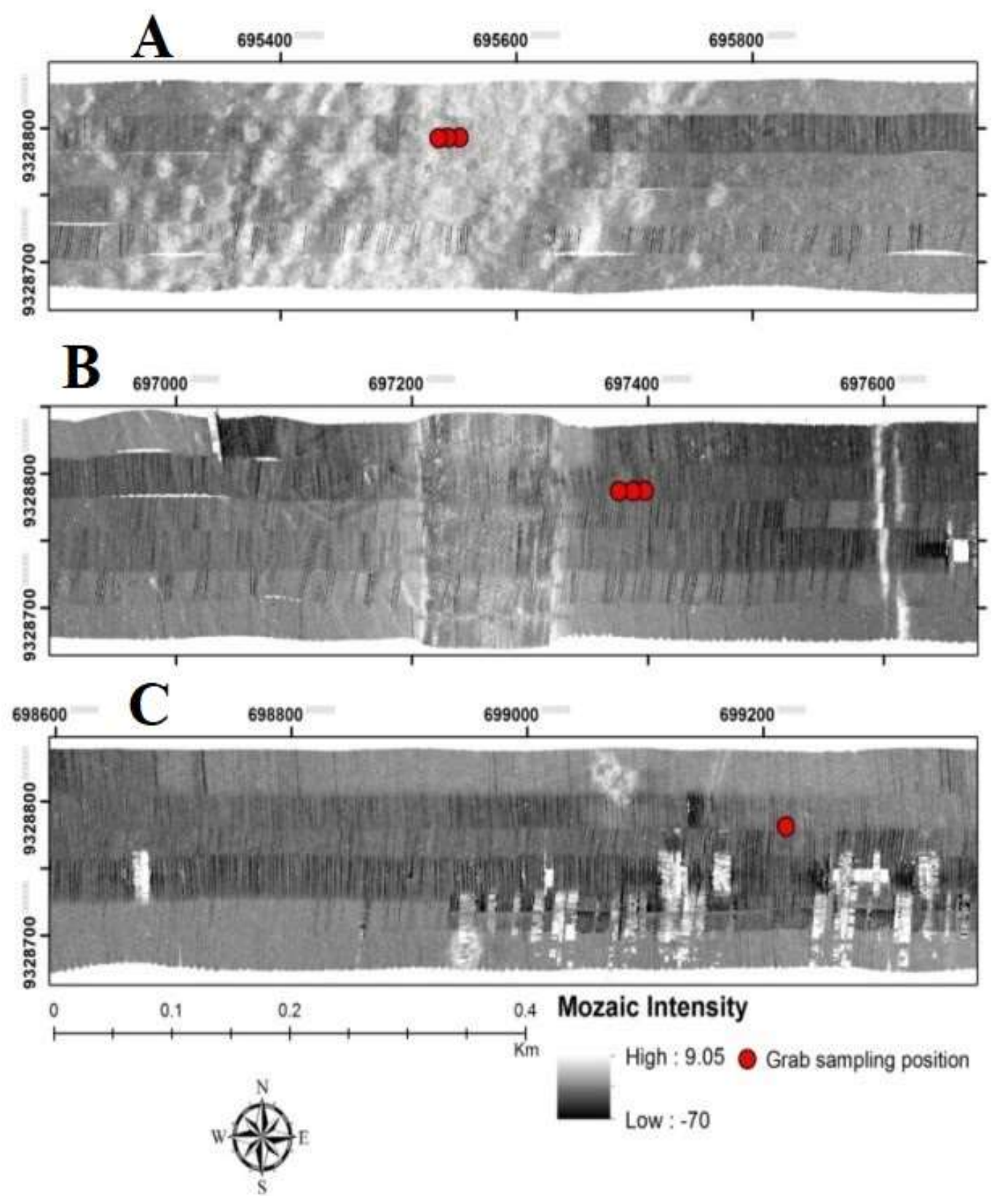

High : 9.05 Grab sampling position

Figure 4. The Backscatter Mosaic in Research Site

The darker data showed lower intensity than the brighter one. The A region has higher mosaic intensity than $\mathrm{B}$ and $\mathrm{C}$ region. The white pattern in $\mathrm{C}$ region showed a bad data acquired in the field. This bad data will affect the bathymetry and classification results then. Bathymetry showed elevation or depth in a specific region. The bathymetry in GIsland sea is presented in Figure 5. 

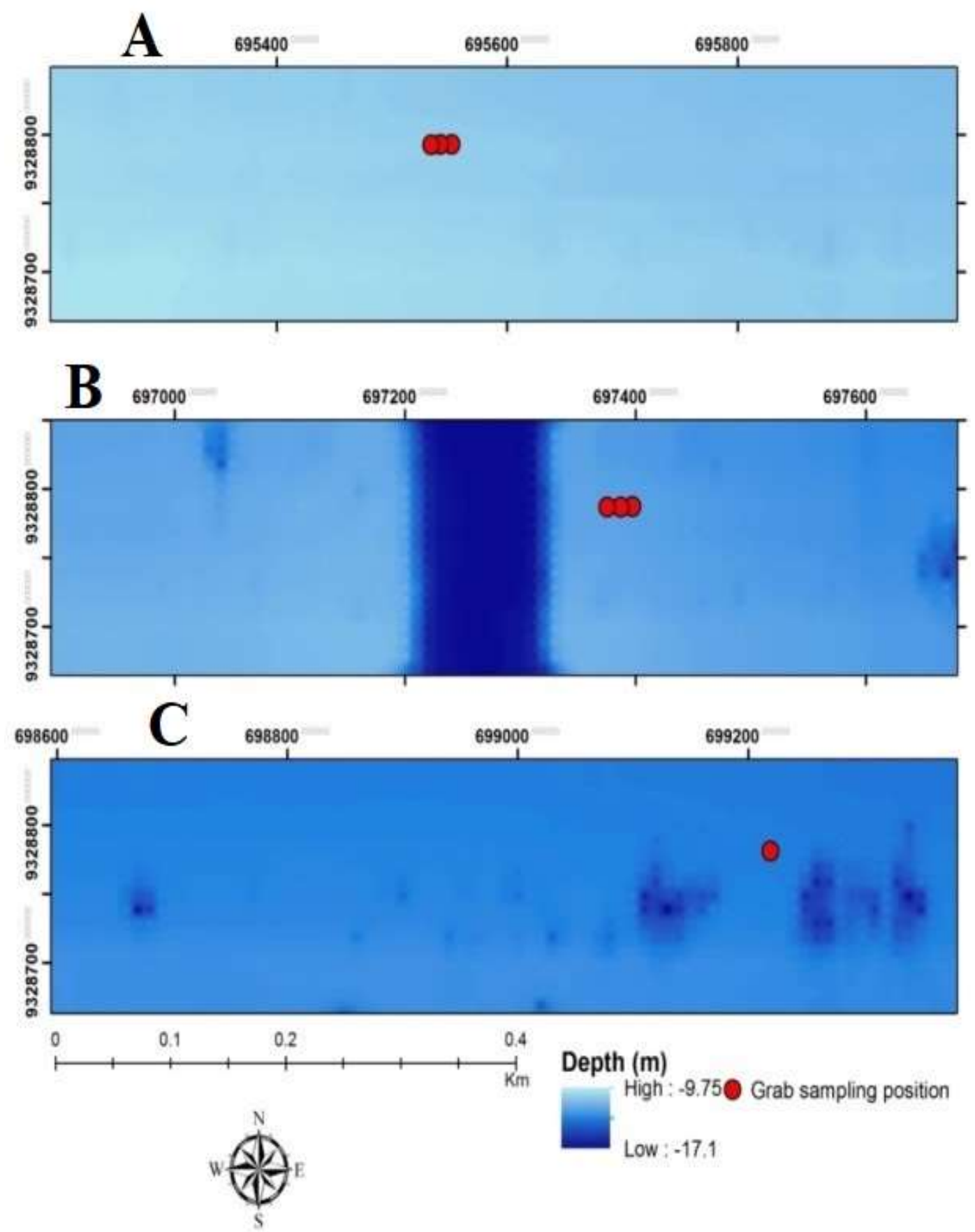

Figure 5. Bathymetry in the Research Site

The bathymetry in G-Island sea is ranged from 9.75 to $17.1 \mathrm{~m}$ and it is categorized as a shallow water. The A region is the shallowest region in the research site. There is a kind of basin in B region which is deeper than other region around it. The basin is ranged about $17 \mathrm{~m}$. This basin is expected as a pipeline or cable canal that going through Seribu Island from Jakarta. The bad data in $\mathrm{C}$ region affect the bathymetry result in $\mathrm{C}$ region. The bathymetry result in $\mathrm{C}$ region should not contain the dark pattern. So it has some errors there.

The classification of the seabed type had been made by using backscatter intensity and grain size measurement. The backscatter intensity is produced by angular range analysis (ARA) method. The backscatter intensity is highly depend on the angle response from 
every single beam of the multibeam instrument. Angle response will make a border of a sediment that will generate the kind of sediment of different composition. The classification of seabed type in this research is presented in Figure 6.
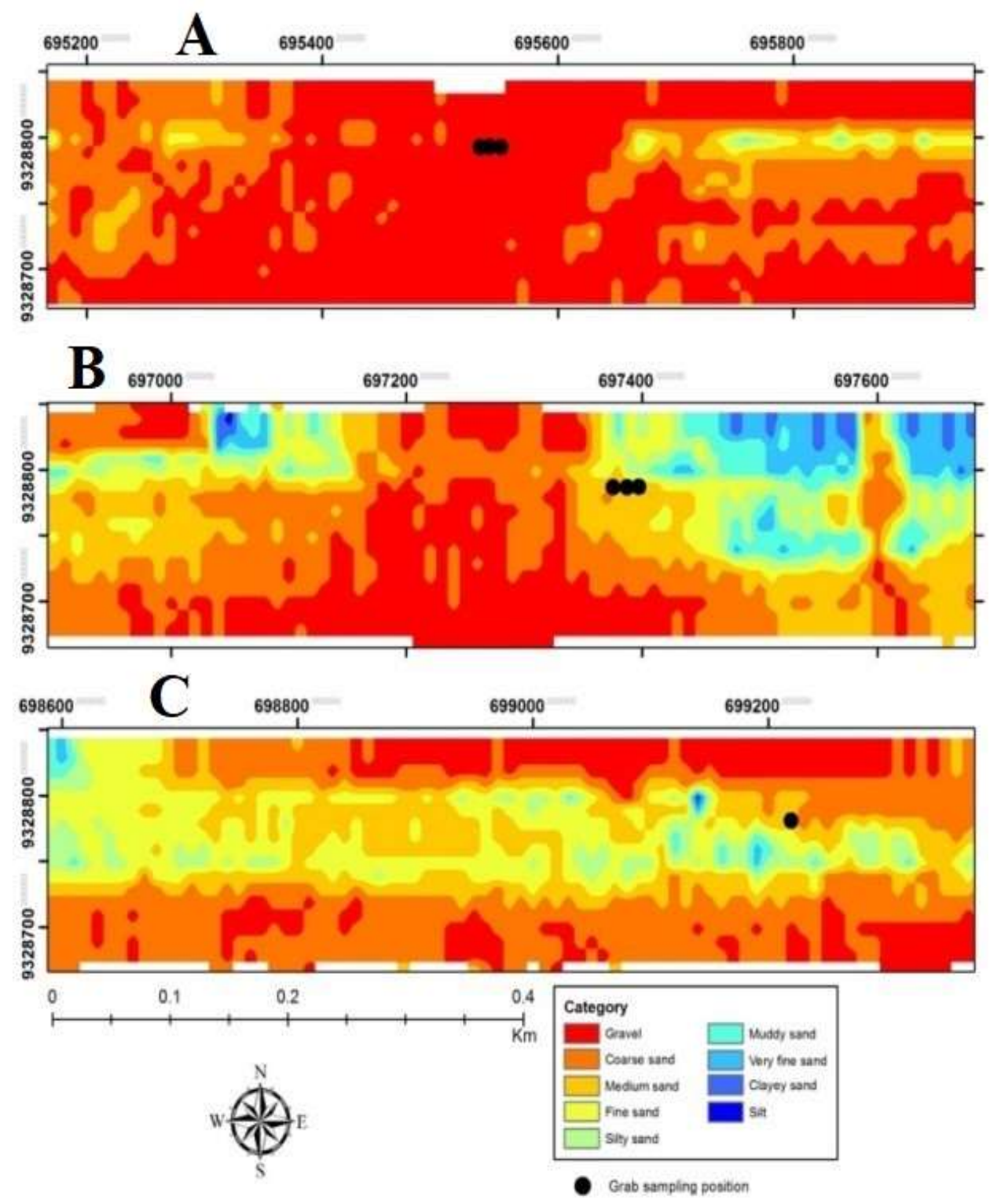

Figure 6. Seafloor Classification Using Backscatter Intensity Data and Grain Size Measurement

Backscatter classification result from seabed could be divided into three major classes; gravel, sand, and silt, and nine minor classes; gravel, coarse sand, medium sand, fine sand, silty sand, muddy sand, very fine sand, clayey sand, and silt. Backscatter value from gravel is higher than sand and silt, because it is harder and denser [21]. The classification showed that in A region, it is dominated by gravel there. Whereas in B region is containing mixed sediment, like sand and silt. In $\mathrm{C}$ region is dominated by sand.

\section{Conclusions}

The seabed sediment had been classified using backscatter intensity data, produced from ARA, and the sediment grain size. The classification still needs more 
improvements to get better result. The backscattering strength from sediment in GIsland is ranged from $-45.38-(-34.71) \mathrm{dB}$ and classified into two classes; coarse sand and very fine sand. Many factors affect the value of backscattering strength of the sediment, not only the grain size but also other physical parameters of sediment affect it as well.

\section{Acknowledgments}

The authors would like to acknowledge the Directorate General of Higher Education (DIKTI), Indonesia, for financially supporting this research through PMDSU Research Grant Scheme no. 136/SP2H/LT/DRPM/IV/2017).

\section{References}

[1] J. Tegowski, J. Nowak, M. Moskalik and K. Szefler, "Seabed classification from multibeam echosounder backscatter data using wavelet transformation and neural network approach", Proceedings of $4^{\text {th }}$ International Conference and Exhibition on Underwater Acoustic, (2011).

[2] H. M. Manik, "Seabed identification and characterization using sonar", Adv. Acoust. Vib., vol. 2012, Article ID 532458, (2012), 5 pages.

[3] R. Che Hasan, D. Ierodiaconou, L. Lurenson and A. Schimel, "Integrating multibeam backscatter angular response, mosaic and bathymetry data for benthic habitat mapping", PLoS ONE 9(5): e97339, (2014).

[4] L. E. Fonseca and L. Mayer, "Remote estimation of surficial seafloor properties through the application angular range analysis to multibeam sonar data", Mar. Geophysical Res, vol. 28, no. 2, (2007), pp. 119126.

[5] H. M. Manik, "Underwater acoustic detection and signal processing near the seabed", In Nikolai Kolev, editor. Sonar Systems; ISBN: 978-953-307-345-3, InTech, (2011).

[6] Z. Huang, P. J. W. Siwabessy, S. Nichol, T. Anderson and B. P. Brooke, "Predictive mapping of seabed cover types using angular response curves of multibeam backscatter data: Testing different feature analysis approaches", Cont Shelf Res, vol. 61, (2013), pp. 12-22.

[7] Z Huang, P. J. W. Siwabessy, S. Nichol and B. P. Brooke, "Predictive mapping of seabed substrata using high-resolution multibeam sonar data: A case study from a shelf with complex geomorphology", Mar. Geol., vol. 357, (2014), pp. 37-52.

[8] L. E. Fonseca, "Angular range analysis of acoustic themes from Stanton Banks Ireland: A link between visual interpretation and multibeam echosounder angular signatures", Appl. Acoust., vol. 70, no. 10, (2009), pp. 1298-1304.

[9] P. J. W. Siwabessy, M. Tran, K. Picard, B. P. Brooke, Z. Huang, N. Smit, D. K. Williams, W. A. Nicholas, S. L. Nichol and I. Atkinson, "Modelling the distribution of hard seabed using calibrated multibeam acoustic backscatter data in tropical, macrotidal embayment: Darwin Harbour, Australia", Mar. Geophys Res, DOI 10.1007/s11001-017-9314-7, (2017).

[10] C. De Moustier and H. Matsumoto, "Seafloor acoustic remote sensing with multibeam echo-sounders and bathymetric sidescan sonar systems", Mar. Geophysical Res, vol. 15, (1993), pp. 27-42.

[11] V. L. Ferrini and R. D. Flood, "The effects of fine-scale surface roughness and grain size on $300 \mathrm{kHz}$ multibeam backscatter intensity in sandy marine sedimentary environments", Mar. Geol., vol. 228, (2006), pp. 153-172.

[12] I. M. Parnum, A. N. Gavrilov, P. J. W. Siwabessy and A. J. Duncan, "Analysis of high frequency multibeam backscatter statistics from different seafloor habitats", S. M. Jesus, O. C. Rodriguez (Eds.), Proceedings of Eighth European Conference on Underwater Acoustics, Carvoeiro, Portugal, (2006).

[13] P. J. W. Siwabessy, A. N. Gavrilov, A. J. Duncan and I. M. Parnum, "Analysis of statistics of backscatter strength from different seafloor habitats", Proceeding of Acoustics, Australian Acoustic Association, Christchurch, New Zealand, (2006), pp. 507-514.

[14] L. E. Fonseca, C. Brown, B. Calder, L. A. Mayer and Y. Rzhanov, "Angular range analysis of acoustic themes from Stanton Banks Ireland: a link between visual interpretation and multibeam echosounder angular signatures", Appl. Acoust., vol. 70, (2009), pp. 1298-1304.

[15] K. S. Davis, N. C. Slowey, I. H. Stender, H. Fiedler, W. R. Bryant and G. Fechner, "Acoustic backscatter and sediment textural properties of inner shelf sands, northeastern Gulf of Mexico", GeoMar Let., vol. 16, (1996), pp. 273-278.

[16] G. De Falco, R. Tonielli, G. Di Martino, S. Innangi, S. Simeone and I. M. Parnum, "Relationships between multibeam backscatter, sediment grain size, and Posidonia oceanica seagrass distribution", Cont Shelf Res., vol. 30, (2010), pp. 1941-1950.

[17] E. R. Lundblad, D. J. Wright, J. Miller, E. M. Larkin, R. Rinehart, D. F. Naar, B. T. Donahue, S. M. Anderson and T. Battista, "A benthic terrain classification scheme for American Samoa", Mar Geod, vol. 29, (2006), pp. 89-111. 
[18] M. F. J. Wilson, B. O’Connell, J. C. Guinan and A. J. Grehan, "Multiscale terrain analysis of multibeam bathymetry data for habitat mapping on the continental slope", Mar. Geol., vol. 30, (2007), pp. 3-35.

[19] P. Dartnell and J. V. Gardner, "Predicting seafloor facies from multibeam bathymetry and backscatter data", Photogramm Eng Remote Sensing, vol. 70, (2004), pp. 1081-1091.

[20] L. E. Fonseca, L. A. Mayer and B. J. Kraft, "Seafloor characterization through the application of AVO analysis to multibeam sonar data", Boundary Influences in High Frequency Shallow Water Acoustics, vol. 340, (2005).

[21] H. M. Manik, "Acoustical measurement and Biot model for coral reef detection and quantification", Adv. Acoust. Vib., vol. 2016, Article ID 2350615, (2016), 11 pages. 